\title{
Hair Aluminum and Manganese Levels in Children with Attention Deficit Hyperactivity disorder
}

\author{
Rehab M. Mhanna ${ }^{*}$; Sameera Sh. Hamid ${ }^{1}$; Salwa M. Toubar ${ }^{2}$; Sahar A. El-Dakroury ${ }^{1}$; \\ Laila M. El-Zalabany ${ }^{1}$
}

\begin{tabular}{|c|c|}
\hline & ABSTRACT \\
\hline $\begin{array}{l}\text { KEYWORDS } \\
\text { Manganese; } \\
\text { Aluminum; } \\
\text { Hair; } \\
\text { ADHD; } \\
\text { Egyptian. }\end{array}$ & $\begin{array}{l}\text { Attention Deficit Hyperactivity Disorder (ADHD) is a common neurobehavioral } \\
\text { disorder among children. Aluminum (AI) and manganese (Mn) are neurotoxic metals } \\
\text { to which children are continuously exposed and may be involved in the pathogenesis } \\
\text { of ADHD. The aim of this work was to evaluate Mn and Al levels in the hair of a } \\
\text { sample of Egyptian ADHD children in relation to the clinical presentation of this } \\
\text { disorder. The study was carried out on } 200 \text { children, divided into two main groups: } \\
\text { the ADHD group including } 100 \text { ADHD children and the control group that } \\
\text { comprised } 100 \text { apparently healthy children. Hair samples were collected and digested } \\
\text { using microwave. Mn and Al levels in hair samples were detected by inductively } \\
\text { coupled plasma optical emission spectrometry (ICP- OES). A statistically significant } \\
\text { difference was found between the ADHD and the control groups regarding Mn levels } \\
\text { especially among the patients with the hyperactive presentation; meanwhile, there } \\
\text { was no significant difference in hair Al levels between the two studied groups. On the } \\
\text { other hand, patients with inattentive presentation showed relatively higher levels of } \\
\text { Al. }\end{array}$ \\
\hline
\end{tabular}

\section{Introduction}

Attention deficit hyperactivity disorder is a chronic, neuro-developmental illness characterized by persistent inattention and/or hyperactivity and impulsivity that are more disturbing than expected for their age leading to functional impairment in several aspects (Austerman, 2015).

Children with ADHD are at high risk to develop many negative outcomes such as antisocial personality disorder, conduct disorders and substance abuse (Caye et al.,

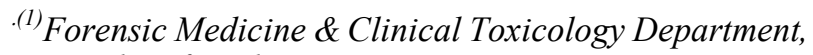
Faculty of Medicine, Mansoura University, Egypt.

${ }^{(2)}$ Psychiatry Department, Faculty of Medicine, Mansoura University, Egypt

*Corresponding author: Telephone: 00201009994998, E-mail: dr_rehabmhanna@mans.edu.eg
}

2019). In Egypt, the reported prevalence of ADHD among primary school children ranged between $6.5 \%$ and $7.9 \%$ (EL-Gendy et al., 2017).

Although ADHD is highly prevalent, its causes are still unclear. It was generally considered a hereditary psychiatric condition, its heritability is about $76 \%$, but also it was suggested that ADHD results from the interaction between genes and environment (Xu et al., 2015), namely neurotoxic metals which cause cognitive impairment (Lee et al., 2018). Children are especially at risk due to the vulnerability of the developing brain to the environmental pollutants at low levels of exposure (El-Morsi et al., 2019).

Aluminum (Al) and manganese (Mn) are neurotoxic metals to which children are continuously exposed (Caito and Aschner, 2015). Manganese is a coenzyme that protects 
against oxidative stress; on the other hand, in high concentration, it generates oxidative damage and adversely affects intellectual functions. In addition, it was observed to influence the dopaminergic neurotransmission in the basal ganglia, which is involved in ADHD pathogenesis (Bouchard et al., 2018).

Some studies have linked aluminum with some diseases involving neuronal degeneration like Alzheimer's disease, Parkinson's disease, and Autism but this link has not been confirmed yet. Al may cause chronic neuronal insult in genetically liable children by several mechanisms including mitochondrial dysfunction and oxidative stress (Morris et al., 2017). However, its association with behavioral disorders has not been recently studied (Tippairote et al., 2019).

The aim of this work is to estimate hair $\mathrm{Mn}$ and $\mathrm{Al}$ levels in a sample of ADHD Egyptian children and to find the relation between their levels and the clinical presentation of this behavioral disorder.

\section{Subjects and Methods:}

The present work is a case-control study that was approved by The Institutional Review Board-Mansoura Faculty of Medicine (code MD/16.08.09). Informed consent was obtained from children's parents; also the children above 7 years were asked for their agreement for participation.

\section{Subjects:}

This study was conducted on 200 children aged between 6 to 15 years. They were divided into two main groups: 1) the ADHD group (100 of medication naive patients diagnosed as attention deficit hyperactivity disorder) who attended the Psychiatric Clinics of Mansoura University Hospital. 2) the control group of 100 apparently healthy subjects who were recruited from children accompanying patients including friends, neighbors, and normal siblings of children in the ADHD group. The two groups were age and sexmatched.

Children with severe neurological or psychiatric disorders such as cerebral palsy, seizures, autistic disorders, mental retardation were excluded. In addition, children with severe birth defects (congenital heart diseases, hereditary metabolic syndrome, and chromosomal anomalies), children on psychotropic medication (e.g. antidepressants) and stimulant drug therapy for ADHD, children with chronic organic diseases (deafness, blindness, severe anemia and renal diseases) and those having chemically treated hair were also excluded.

Children with ADHD were assessed by a professional psychiatrist and diagnosis was performed based on Diagnostic and Statistical Manual of mental disorders (DSM-V) standard according to the American Psychiatric Association (APA, 2013).

Based on the types of symptoms, DSMIV-TR suggested three clinical variants (presentations) for ADHD (Gomez et al., 2016): Combined Presentation: if at least 6 inattention and 6 Hyperactivity/Impulsivity symptoms were present for the past 6 months.

Predominantly Inattentive Presentation: if at least 6 inattention symptoms but not hyperactivity/ impulsivity were present for the past six months. Predominantly Hyperactive/ Impulsive Presentation: if presence of at least 6 Hyperactivity/Impulsivity symptoms but not inattention were present for the past six months.

All the parents of participating children filled out a questionnaire, concerning sociodemographic data, sources of drinking water, using Al cooking utensils and family history of ADHD. 
Sample collection:

Hair samples were collected from all subjects in the study from the nape region using clean ceramic bladed scissors to avoid sample contamination with exogenous metals which usually occurs when using regular stainless steel scissors. Half a gram of hair (Michalak et al., 2012) was obtained for the hair metal assay- as instructed by Tanta University Central Lab where the analysis took place. Only the proximal portion $(5 \mathrm{~cm})$ of the hair strands was acquired as samples which were placed in air-tight prewashed plastic zip lock bags, labeled and stored in room temperature until transported to the lab for analysis (Jursa et al., 2018).

\section{Hair metal analysis:}

The hair was cut into 5-mm pieces then washed three times according to the procedure recommended by the International Atomic Energy Agency Advisory Group using acetone: water $(1: 3)$ to remove surface dirt and exogenous contaminants then dried before analysis at $50^{\circ} \mathrm{C}$ oven (Serdar et al., 2012).

According to the manufacturer instructions; each sample was placed in an acid-washed polypropylene tube with $10 \mathrm{ml}$ of HNO3 (69\%) EMSURE® ACS, Reag. PhEur Sigma-Aldrich. After centrifuging for 5 minutes, the hair sample was transferred into Ethos-Easy Microwave Digestion apparatus, to undergo closed vessel microwave digestion.

All digested samples were analyzed by using Optima ${ }^{\mathrm{TM}} 7000$ DV ICP-OES (Integrated Coupled Plasma Optical Emission Spectroscopy) apparatus - Perkin Elmer Company, Germany at the Central Laboratory in Tanta University. For the preparation of standard solutions, dilutions $(0.5,1,1.5,2,2.5$, $3,3.5,4 \mathrm{mg} / \mathrm{L}$ ) were prepared using, the multielemental standard solution IV $(100 \cdot \mathrm{mg} / \mathrm{L}$ CertiPUR ${ }^{\circledR}$, Merck) diluted in $\mathrm{HNO} 32 \%$.
These standards were measured using Inductively Coupled Plasma "ICP", to build up the standard curve. Later, this curve was used to measure the samples by WINLAB32Software. The detection limits for $\mathrm{Mn}$ and $\mathrm{Al}$ were $0.03 \mu \mathrm{g} / \mathrm{dl}$ and $0.9 \mu \mathrm{g} / \mathrm{dl}$ respectively. The concentration of hair $\mathrm{Mn}$ and $\mathrm{Al}$ was reported in $\mu \mathrm{g} / \mathrm{g}$.

\section{Statistical analysis:}

SPSS version 22 was used for data analysis. Kolmogorov-Smirnov test was first used to test the normality of data with onesample. Qualitative data were described using numbers and percentages. Association between categorical variables was tested using chisquare. The two groups were compared with Student's t-test (parametric data) and MannWhitney tests (nonparametric data), while the Kruskal-Wallis test was used to compare more than two medians. Binary stepwise logistic regression analysis was used for prediction of independent variables of binary outcome. Adjusted odds ratios and their $95 \%$ confidence interval were calculated.

\section{Results:}

The socio-demographic characteristics of the studied subjects as regards age, sex, residence, as well as the sources of drinking water and the usage of aluminum cooking pots, were illustrated in table (1).

Figure (1) is a pie chart showing the distribution of family history of ADHD among the studied cases. Table (2) shows the percentage of each of the three ADHD presentations among the ADHD group, most of them were diagnosed as combined ADHD $(44 \%)$. 
Table (1): Demographic characteristics among the studied children $(n=200)$.

\begin{tabular}{|c|c|c|c|c|c|}
\hline Parameter & \multicolumn{2}{|c|}{$\begin{array}{c}\text { Control group } \\
\mathbf{n}=100\end{array}$} & \multicolumn{2}{|c|}{$\begin{array}{c}\text { ADHD group } \\
\mathbf{n}=100\end{array}$} & $\begin{array}{c}\text { Test of } \\
\text { significance }\end{array}$ \\
\hline $\begin{array}{l}\text { Age/years } \\
\quad \text { Mean } \pm \text { SD }\end{array}$ & \multicolumn{2}{|c|}{$8.60 \pm 1.94$} & \multicolumn{2}{|c|}{$8.47 \pm 1.86$} & $\begin{array}{l}t=0.48 \\
p=0.63\end{array}$ \\
\hline $\begin{array}{l}\text { Sex } \\
\qquad \begin{array}{l}\text { Male } \\
\text { Female }\end{array}\end{array}$ & $\begin{array}{c}\mathrm{n} \\
77 \\
23\end{array}$ & $\begin{array}{c}\% \\
77.0 \\
23.0\end{array}$ & $\begin{array}{c}\mathrm{n} \\
74 \\
26\end{array}$ & $\begin{array}{c}\% \\
74.0 \\
26.0\end{array}$ & $\begin{array}{l}\chi^{2}=0.62 \\
p=0.24\end{array}$ \\
\hline $\begin{array}{c}\text { Residence } \\
\text { Rural } \\
\text { Urban }\end{array}$ & $\begin{array}{l}32 \\
68\end{array}$ & $\begin{array}{l}32.0 \\
68.0\end{array}$ & $\begin{array}{l}45 \\
55\end{array}$ & $\begin{array}{l}45.0 \\
55.0\end{array}$ & $\begin{aligned} \chi^{2} & =3.56 \\
p & =0.06\end{aligned}$ \\
\hline $\begin{array}{l}\text { Usage of aluminum cooking pots and foil: } \\
\text { Positive } \\
\text { Negative }\end{array}$ & $\begin{array}{c}93 \\
7\end{array}$ & $\begin{array}{c}93.0 \\
7.0\end{array}$ & $\begin{array}{c}95 \\
5\end{array}$ & $\begin{array}{c}95.0 \\
5.0\end{array}$ & $\begin{array}{l}\chi^{2}=0.36 \\
\mathrm{p}=0.55\end{array}$ \\
\hline $\begin{array}{l}\text { Sources of drinking water } \\
\text { Filtered } \\
\text { Un-filtered } \\
\text { Underground }\end{array}$ & $\begin{array}{l}58 \\
39 \\
3\end{array}$ & $\begin{array}{r}58.0 \\
39.0 \\
3.0\end{array}$ & $\begin{array}{l}44 \\
51 \\
5\end{array}$ & $\begin{array}{l}44.0 \\
51.0 \\
5.0\end{array}$ & $\begin{array}{c}\chi^{2}=4.02 \\
\mathrm{p}=0.13\end{array}$ \\
\hline
\end{tabular}

n: number, SD: standard deviation, t: Student test, $\chi^{2}$ : Chi-Square test, ${ }^{*} p$ value: significant at $\leq 0.05$.

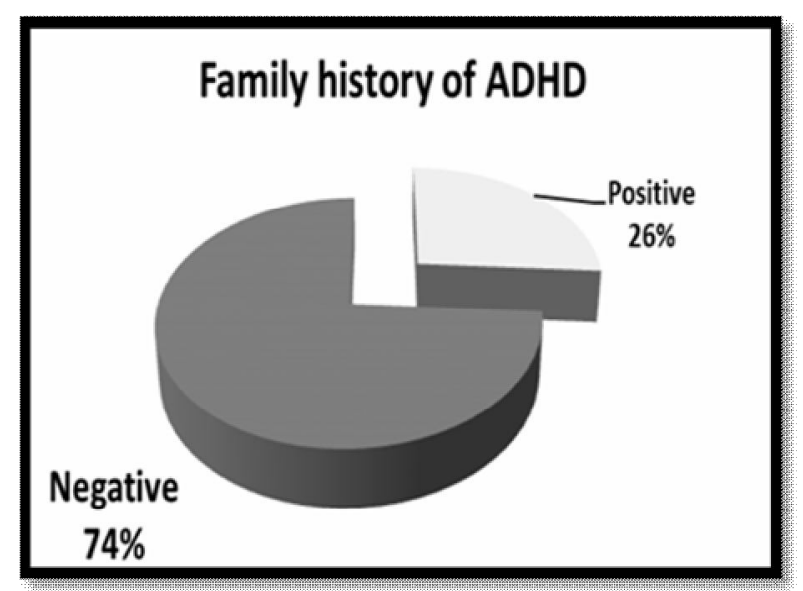

Fig. (1): A pie chart showing the distribution of family history of Attention Deficit Hyperactivity Disorder in studied cases group $(\mathrm{n}=100)$.
Table (2): Classification of ADHD presentation among the studied children according to DSM-V criteria $(n=100)$.

\begin{tabular}{|c|c|c|c|}
\hline \multirow{2}{*}{$\begin{array}{c}\text { ADHD clinical } \\
\text { presentation }\end{array}$} & \multicolumn{3}{|c|}{ ADHD cases } \\
& \multicolumn{2}{|c|}{$\mathrm{n}=100$} \\
\hline \multirow{3}{*}{ H } & \multicolumn{2}{|c|}{20} & \multirow{3}{*}{20.0} \\
\cline { 2 - 3 } & Males & 16 & \multirow{3}{*}{36.0} \\
\cline { 2 - 3 } & Females & 4 & \\
\hline \multirow{4}{*}{ I } & \multicolumn{2}{|c|}{36} & \\
\cline { 2 - 3 } & Males & 22 & \multirow{3}{*}{44.0} \\
\cline { 2 - 3 } & Females & 14 & \\
\hline \multirow{3}{*}{ C } & 44 & \\
\cline { 2 - 3 } & Males & 36 & 8 \\
\cline { 2 - 3 } & Females & 8 \\
\hline
\end{tabular}

$\mathrm{n}$ : number, H: hyperactive presentation, I: inattentive presentation, $\mathrm{C}$ : combined presentation, ADHD: Attention deficit hyperactivity disorder, DSM-V: Diagnostic and Statistical Manual of Mental Disorders, 5th Edition. 
Table (3) shows that the hair manganese level was significantly correlated with the source of drinking water $(p<0.001)$. It was the highest in hair samples of children drinking underground water, followed by those drinking unfiltered tap water and the least in cases drinking filtered tap water. Aluminum hair level was significantly correlated with using aluminum cooking utensils $(p=0.001)$, as shown in table (4).

Table (3): Hair Manganese (Mn) level in relation to the source of drinking water in the studied subjects $(\mathrm{n}=200)$.

\begin{tabular}{|l|l|c|c|}
\hline \multirow{2}{*}{ Source of drinking water } & \multicolumn{2}{|c|}{ Hair Mn level in studied subjects $(\boldsymbol{\mu g} / \mathbf{g})$} & Test of significance \\
\cline { 3 - 4 } & \multicolumn{2}{|c|}{$\mathbf{n = 2 0 0}$} & $\mathrm{KW}$ \\
& & $\mathrm{p}<0.001^{*}$ \\
\hline \multirow{3}{*}{ Unfiltered tap water } & Mean $\pm \mathrm{SD}$ & $4.45 \pm 2.1$ & $\mathrm{p} 1=<0.001^{*}$ \\
& Median & 4.13 & \\
\hline \multirow{3}{*}{ Filtered tap water } & Min-Max & $(0.22-14.02)$ & $\mathrm{p} 2<0.001^{*}$ \\
& Mean $\pm \mathrm{SD}$ & $2.67 \pm 1.34$ & \\
\hline \multirow{3}{*}{ Underground water } & Median & 2.75 & $\mathrm{p} 3<0.001^{*}$ \\
& Min-Max & $(0.08-9.03)$ & \\
\hline
\end{tabular}

n:number, SD: standard deviation, Min- Max: minimum- maximum ranges, KW: Kruskal-Wallis test, *p value significant at $\leq 0.05$. p1: comparison between not filtered and filtered, $\mathrm{p} 2$ : comparison between not filtered and underground, p3: comparison between filtered and underground (significance within groups was tested by MannWhitney U test).

Table (4): Hair Aluminum (Al) level in relation to usage of aluminum cooking utensils in the studied subjects $(n=200)$.

\begin{tabular}{|c|c|c|c|}
\hline $\begin{array}{l}\text { Use of Aluminum cooking } \\
\text { utensils }\end{array}$ & \multicolumn{2}{|c|}{$\begin{array}{l}\text { Hair Al level in studied subjects }(\mu \mathrm{g} / \mathrm{g}) \\
\qquad \mathrm{n}=\mathbf{2 0 0}\end{array}$} & $\begin{array}{c}\text { Test of } \\
\text { significance }\end{array}$ \\
\hline Negative & $\begin{array}{l}\text { Mean } \pm \text { SD } \\
\text { Median } \\
\text { Min-Max }\end{array}$ & $\begin{array}{c}11.43 \pm 4.9 \\
9.78 \\
(5.21-20.42)\end{array}$ & $\mathrm{z}=4.31$ \\
\hline Positive & $\begin{array}{l}\text { Mean } \pm \text { SD } \\
\text { Median } \\
\text { Min-Max }\end{array}$ & $\begin{array}{c}21.87 \pm 9.14 \\
19.7 \\
(8.1-62.88)\end{array}$ & $p=0.001 *$ \\
\hline
\end{tabular}

n: number, SD: standard deviation, Min- Max: minimum- maximum ranges, z: Mann-Whitney U, * p value significant at $\leq 0.05$. 
Hair Mn level was significantly higher in ADHD cases than the control subjects $(p<0.001)$. Hair Al level was slightly higher in control group than in ADHD cases but with no statistical significance $(\mathrm{p}=0.21)$ as shown in table (5). Regression analysis for prediction of ADHD among the studied cases was done as shown in table (6). It demonstrated that each $1 \mu \mathrm{g} / \mathrm{g}$ increase in hair Mn level is associated with 1.28 folds increase in the risk of developing ADHD.

Table (5): Hair manganese and aluminum levels among the studied control and ADHD groups $(\mathrm{n}=200)$.

\begin{tabular}{|c|c|c|c|}
\hline $\begin{array}{c}\text { Hair metal analysis } \\
(\mu \mathrm{g} / \mathrm{g})\end{array}$ & $\begin{array}{c}\text { Control group } \\
\mathbf{n}=\mathbf{1 0 0} \\
\end{array}$ & $\begin{array}{c}\text { ADHD group } \\
\mathbf{n}=\mathbf{1 0 0} \\
\end{array}$ & $\begin{array}{c}\text { Test of } \\
\text { significance } \\
\end{array}$ \\
\hline \multicolumn{3}{|l|}{ Manganese } & \multirow{5}{*}{$\begin{array}{c}\mathrm{z}=4.02 \\
\mathrm{p}<0.001 *\end{array}$} \\
\hline $\operatorname{Mean} \pm$ SD & $3.20 \pm 1.9$ & $4.25 \pm 2.47$ & \\
\hline Median & 2.97 & 3.78 & \\
\hline (Min-Max) & $(0.08-12.76)$ & $(0.22-15.98)$ & \\
\hline IQR & $(2.11-3.88)$ & $(2.98-5.08)$ & \\
\hline \multicolumn{3}{|l|}{ Aluminum } & \multirow{5}{*}{$\begin{array}{l}\mathrm{z}=1.25 \\
\mathrm{p}=0.21\end{array}$} \\
\hline $\operatorname{Mean} \pm$ SD & $22.15 \pm 9.9$ & $20.32 \pm 8.5$ & \\
\hline Median & 20.87 & 18.73 & \\
\hline (Min-Max) & $(7.6-62.88)$ & $(5.21-55.08)$ & \\
\hline IQR & $(15.38-26.24)$ & $(14.95-25.29)$ & \\
\hline
\end{tabular}

SD: standard deviation, Min- Max: minimum- maximum range, $\mathrm{z}$ : Mann Whitney $\mathrm{U}$ test, IQR: Inter-quartile range, ${ }^{*} \mathrm{P}$ value significant at $\leq 0.05$, n: number, ADHD: Attention deficit hyperactivity disorder.

Table (6): Regression analysis for prediction of ADHD ( $\mathrm{n}=200)$.

\begin{tabular}{|l|c|c|c|c|c|}
\hline \multirow{2}{*}{ Item } & \multirow{2}{*}{ B } & \multirow{2}{*}{$\mathbf{p}$} & \multirow{2}{*}{ odds ratio } & \multicolumn{2}{c|}{ 95\% C.I. } \\
\cline { 5 - 6 } & & & & Lower & Upper \\
\hline Aluminum $(\mu \mathrm{g} / \mathrm{g})$ & -0.027 & 0.100 & 0.973 & 0.942 & 1.005 \\
\hline Manganese $(\mu \mathrm{g} / \mathrm{g})$ & 0.254 & $0.001 *$ & 1.289 & 1.105 & 1.504 \\
\hline Constant & -0.356 & 0.432 & 0.701 & & \\
\hline
\end{tabular}

B: standardized beta coefficient, $* \mathrm{p}$ value significant at $\leq 0.05$, C.I.: Confidence Interval, ADHD: Attention deficit hyperactivity disorder.

Table (7) demonstrates the association between hair Mn and Al levels with the three clinical presentations of ADHD. A significantly higher mean Mn level was detected in children with hyperactive presentation and combined groups than in the inattentive presentation and in the combined subtype than the inattentive group. Meanwhile, the difference between the hyperactive and combined subtypes was insignificant. In addition, Al levels were significantly higher in inattentive than the other two groups. 
Table (7): Statistical association between ADHD presentation according to DSM-V classification and Manganese \& Aluminum hair levels among the studied cases $(n=100)$.

\begin{tabular}{|l|c|c|c|c|c|}
\hline \multirow{2}{*}{$\begin{array}{c}\text { Hair mineral } \\
\text { analysis }(\mu \mathrm{g} / \mathrm{g})\end{array}$} & $\begin{array}{c}\mathrm{H} \\
\mathrm{n}=20\end{array}$ & $\mathrm{n}=36$ & $\mathrm{I}$ & $\begin{array}{c}\text { Test of } \\
\text { significance }\end{array}$ & $\begin{array}{c}\text { Within } \\
\text { group } \\
\text { significance }\end{array}$ \\
\cline { 2 - 4 } & \multicolumn{7}{|c|}{ Manganese } & $\mathrm{KW}$ & \\
\hline Mean \pm SD & $5.32 \pm 2.47$ & $3.16 \pm 1.7$ & $4.67 \pm 2.6$ & & $\mathrm{p} 1<0.001^{*}$ \\
Median & 4.59 & 3.11 & 4.09 & $\mathrm{p}<0.001^{*}$ & $\mathrm{p} 2=0.22$ \\
$($ Min-Max) & $(2.14-12.23)$ & $(0.22-9.88)$ & $(0.88-15.98)$ & & $\mathrm{p} 3=0.001^{*}$ \\
\hline \multicolumn{7}{|c|}{ Aluminum } & & \\
\hline Mean \pm SD & $14.46 \pm 4.68$ & $25.74 \pm 9.89$ & $18.56 \pm 5.88$ & & $\mathrm{p} 1<0.001^{*}$ \\
Median & 14.5 & 25.7 & 17.4 & $\mathrm{p}<0.001^{*}$ & $\mathrm{p} 2=0.007^{*}$ \\
Min-Max) & $(5.21-23.3)$ & $(7.39-55.08)$ & $(7.39-55.08)$ & & $\mathrm{p} 3<0.001^{*}$ \\
\hline
\end{tabular}

n: number, SD: standard deviation, Min- Max: minimum- maximum range, H: hyperactive presentation, I: inattentive presentation, $\mathrm{C}$ : combined presentation, $\mathrm{KW}$ : Kruskal Wallis test, ${ }^{*} \mathrm{P}$ value significant at $\leq 0.05$, p1: Comparison between hyperactive subtype and inattentive subtype cases, p2: Comparison between hyperactive subtype and combined subtype cases, p3: Comparison between inattentive subtype and combined subtype cases by Mann-Whitney U test, ADHD: Attention deficit hyperactivity disorder, DSM-V: Diagnostic and Statistical Manual of Mental Disorders, 5th Edition.

\section{Discussion:}

In the present study, levels of manganese and aluminum in hair were estimated to evaluate chronic exposure of the control and ADHD children.

This study was done on children (6-15 years), whose symptoms became noticeable and established after attending school. Male to female ratio in cases was found to be $(2.8: 1)$ which is consistent with the higher prevalence of ADHD diagnosis among boys. A study conducted by Mowlem et al. (2019) supported this finding, with a male to female ratio (2.5:1). Also, Tippairote et al. (2017) reported the same finding where the ratio was $(2.2: 1)$. This could be explained by the differences in rates of diagnosis of ADHD types as girls usually have predominantly inattentive symptoms which are less annoying to the parents.

According to the present work, a positive family history of ADHD among parents and siblings was found in $26 \%$ of cases which was supported by Altun and Altun (2018) who reported that $20 \%$ of the studied preschool children had a positive family history of ADHD. Also, El-Nemr et al. (2015) found that $22 \%$ out of 96 ADHD children had a positive family history of ADHD.

The present work demonstrates that inattentive subtype represented $36 \%$ of cases and was slightly higher in males (1.57:1), while the hyperactive-impulsive subtype represented $20 \%$-with a male to female ratio of (4:1) - and $44 \%$ for the combined subtype which was predominant in males (4.5:1).

The current findings are in agreement with the results of Farahat et al. (2014) who stated that the percentage of the inattentive presentation was $31.5 \%$ and was slightly higher in females; the combined presentation was $48 \%$ and was more common in males. However, the hyperactive-impulsive presentation represented $20.5 \%$ with a male to female ratio of $(1.4: 1)$. 
Additionally, Abd El Naby and Naguib (2018) reported that the inattentive and combined variants represented $12 \%$ and $68 \%$ respectively, while the hyperactive ADHD type represent $20 \%$ of the studied cases. Furthermore, El-Morsi et al. (2019) found that the commonest presentation of ADHD in Egyptian children was the combined form $(60.8 \%)$.

Since $\mathrm{Mn}$ is abundant in groundwater, high concentrations have been recorded in populations whose main source of drinking is groundwater (Iyare, 2019). In Egypt, the concentrations of $\mathrm{Mn}$ in the Nile water was found to be between 0.5 and $1.45(\mathrm{mg} / \mathrm{l})$, which exceeded World Health Organization and Egyptian Standard for safe water limits for drinking water guidelines ( $4 \mathrm{mg} / 1$ for adults) (Abdel-Satar et al., 2017).

However, its level in domestic tap water (unfiltered) may vary according to the efficiency of water treatment and the integrity of water pipe systems according to the location (El-Kowrany et al., 2016).

The results of the questionnaire applied on the two studied groups in the present work illustrate that $3 \%$ of the control group and $5 \%$ of the cases stated that they used underground water obtained by pumps for drinking and cooking purposes. $39 \%$ of control subjects and $51 \%$ of cases used unfiltered tap water, whereas $58 \%$ of control children and $44 \%$ of the cases depended on filtered water by applying domestic filters of various types and efficiency to water taps.

In the current study, the level of hair manganese was significantly associated with the source of drinking water, which was the highest in the group drinking underground water $(9.12 \pm 2.96 \mu \mathrm{g} / \mathrm{g})$, followed by the group drinking unfiltered water $(4.45 \pm 2.1 \mu \mathrm{g} / \mathrm{g})$ and then the group drinking filtered water $(2.67 \pm 1.34 \mu \mathrm{g} / \mathrm{g})$.
This is in agreement with Ntihabose et al. (2018) who assessed hair, saliva, and toenails as biomarkers of low-level manganese exposure from drinking water in school-aged children. Only hair and toenails exhibited a correlation $(\mathrm{r}=0.29)$ with manganese exposure from drinking water.

Moreover, Dion et al. (2017) and do Nascimento et al. (2015) in their studies concluded that greater $\mathrm{Mn}$ in drinking water was associated with greater Mn levels in hair.

Worldwide accepted and implemented universal reference ranges for hair minerals with the consideration of the methodology used for detection are lacking (Mikulewicz et al., 2013), some studies used reference values for hair $\mathrm{Mn}<1.2 \mu \mathrm{g} / \mathrm{g}$ (Menezes-Fihlo et al., 2009), while O'Neal and Zheng (2015) denoted normal Mn hair level to be $2.6 \mu \mathrm{g} / \mathrm{g}$. It can be concluded that in the current study the mean hair $\mathrm{Mn}$ in the studied subjects is generally high.

It was reported that aluminum present in cooking pots can cause ingestion of large amounts of aluminum. Intolerable amounts of aluminum can be ingested with one meal cooked using aluminum (more than $150 \mathrm{mg}$ ), especially in the case of acidic dishes like tomato sauce (Weidenhamer et al., 2017).

In a study done by Osman et al. (2017) on a group of adolescents from residents in food catering establishment, the average weekly dietary aluminum exposure level for an adolescent was $2.223 \mathrm{mg} / \mathrm{kg}$ body-weight/week which exceeds the Provisional Tolerable Weekly Intake (PTWI) (2 $\mathrm{mg} / \mathrm{kg}$ bodyweight/week) established by the Joint Food and Agriculture Organization/World Health Organization Expert (FAO/WHO) Committee in 2011 (Sato et al., 2014).

Also, in a study done in Belgium, it was shown that $\mathrm{Al}$ foil usage in cooking contributes up to $64 \%$ of the total $\mathrm{Al}$ intake. It was claimed that avoidance of $\mathrm{Al}$ cooking utensils may 
significantly decrease the risk of exceeding the aluminum PTWI in food (Cammaerts and Cammaerts, 2018).

In the present work, the results of the questionnaire revealed that $93 \%$ of control and $95 \%$ of ADHD cases use Al cooking pots and Al foil. Moreover, hair Al level was significantly associated with using aluminum cooking utensils.

In accordance with the current study, Mohamed et al. (2015) investigated hair aluminum levels in autistic children in comparison to healthy controls. They found that the usage of aluminum cooking utensils was associated with higher $\mathrm{Al}$ hair levels.

In the present work, manganese was significantly higher in ADHD cases than control subjects. Shin et al. (2015) also found that the hair Mn concentrations in the ADHD group were slightly higher than the control group. They revealed significant association between hair Mn levels and ADHD after statistical control for covariates.

In the current study, Mn level was significantly higher in the hyperactive and the combined presentation groups than inattentive, but the difference between the hyperactive and the combined presentations was insignificant.

These results agreed with that of Bouchard et al. (2007), who assessed ADHD behaviors in relation to hair $\mathrm{Mn}$ levels in children. They found that the correlation was significant for hyperactivity, but not for inattention.

On the other hand, Oulhote et al. (2014) examined the relationship between neurobehavioral functions and hair $\mathrm{Mn}$ in Canada. Higher levels of exposure to manganese were associated with deterioration in attention, and motor functions, but not hyperactivity.

Also, Rodrigues et al. (2018) evaluated behavioral effects in children in relation to $\mathrm{Mn}$ exposure. Occipital hair, toenails, and blood samples were collected. The Child Behavior Check List (CBCL) was used to assess children's behavior. Hair and blood manganese levels were not associated with any behavioral abnormality. Non-linear association between toenails manganese and aggressive behavior was observed. This may be explained by different ADHD rating scales used or different techniques applied for hair samples washing and analysis.

In the current work, the mean $\mathrm{Al}$ hair level is higher in the control group $(22.15 \pm 9.9$ $\mu \mathrm{g} / \mathrm{g})$ than in ADHD cases $(20.32 \pm 8.5 \mu \mathrm{g} / \mathrm{g})$, but the difference was not of statistical significance.

More or less similar results were claimed by Tippairote et al. (2017) in Bangkok, but the mean hair aluminum levels in ADHD cases and control subjects were lower than those in the current study. This may be explained by different selected age group (3-7 years) or by using ICP-MS rather than ICP-OES.

The mean hair aluminum levels in the current works are considered high, when compared to the reference interval (1.2-9.2 $\mu \mathrm{g} / \mathrm{g}$ ) mentioned by Underwood (1971).

When comparing the mean hair aluminum levels among the three presentations of ADHD among the cases, it was observed that they were significantly higher in children with inattentive presentation than those with combined presentation and in combined than in hyperactive presentation.

These results are supported by Iqbal et al. (2018) who found that high level of aluminum may be associated with cognitive impairment as indicated by decreased mini- mental state examination (MMSE) scores. On the other hand, Tippairote et al. (2017) reported that there was no significant difference in hair $\mathrm{Al}$ levels among the three ADHD presentations.

It is concluded that children with autism spectrum disorders (ASD) and ADHD may have greater toxic metal body burden compared 
with healthy children. It is suggested that ADHD and ASD could be considered as related conditions that likely share many possible contributory factors due to similarities in brain pathology and symptomatology (Kern et al., 2015).

There may be some argument that children with ADHD are not the only children exposed to potentially toxic metals; it may be the result of a greater ability to accumulate toxins, which in turn leads to an alteration of biochemical processes (Shaw and Tomljenovic, 2013).

In addition, poor eating habits in ADHD children (Ptacek et al., 2010) may lead to deficiency in essential elements as calcium, copper, Zn, and iron which increase gastrointestinal uptake of metals including Mn and Al. Moreover, ADHD patients may have problems with the chemical pathway that detoxify these metals (Poujois et al., 2016).

\section{Conclusion:}

The present study provides evidence that higher hair Mn levels were associated with drinking unfiltered or underground water, and that exposure to $\mathrm{Mn}$ is a risk factor for the development of ADHD especially the hyperactive variant. Furthermore, higher hair Al levels were associated with using aluminum cooking utensils, and with development of inattentive symptoms.

\section{Acknowledgment:}

The authors would like to acknowledge colleagues in Psychiatry Department for their help in collecting the hair samples.
References:

Abd El Naby, S.A. and Naguib, Y.M. (2018): "Sociodemographic, electrophysiological, and biochemical profiles in children with attention deficit hyperactivity disorder and/or epilepsy". Behav. Neurol., 2018: 1-12. ID 8932817.

Abdel-Satar, A.M.; Ali, M.H. and Goher, M.E. (2017): "Indices of water quality and metal pollution of Nile River, Egypt". Egypt. J. Aquat. Res., 43(1): 21-29.

Altun, H. and Altun, I. (2018): "Risk of mild head injury in preschool children: relationship to attention deficit hyperactivity disorder symptoms". Child's Nerv. Syst., 34(7): 1353-1359.

American Psychiatric Association (2013): Diagnostic and Statistical Manual of Mental Disorders. $5^{\text {th }}$ edition (DSM-V), American Psychiatric Association, Washington, DC.

Austerman, J. (2015): "ADHD and behavioral disorders: Assessment, management, and an update from DSM-5". Clevel. Clin. J. Med., 82(11): S2-7.

Bouchard, M.; Laforest, F.; Vandelac, L.; et al. (2007): "Hair manganese and hyperactive behaviors: Pilot study of school-age children exposed through tap water". Environ. Health Perspect., 115:122-127. doi:10.1289/ehp.9504

Bouchard, M.F.; Surette, C.; Cormier, P.; et al. (2018): "Low level exposure to manganese from drinking water and cognition in school-age children". Neurotoxicology, 64:110-117.

Caito, S. and Aschner, M. (2015): "Neurotoxicity of metals". Handb. Clin. Neurol., 131:169-189.

Cammaerts M.C. and Cammaerts, R. (2018): "Is metal leakage from aluminum foil without adverse effects? A study on 
ants as Models". J. Nutr. Health Sci., 5(1): 103-118.

Caye, A.; Swanson, J.M.; Coghill, D.; et al. (2019): "Treatment strategies for ADHD: an evidence-based guide to select optimal treatment". Mol. Psychiatry, 24(3): 390408.

Dion, L.; Saint-Amour, D.; Sauvéd, S.; et al. (2017): "Changes in water manganese levels and longitudinal assessment of intellectual function in children exposed through drinking water". Neurotoxicology, 64:118-125.

do Nascimento, S.N.; Barth, A.; Goethel, G.; et al. (2015): "Cognitive deficits and ALA-D-inhibition in children exposed to multiple metals". Environ. Res., 136: 387-395.

EL-Gendy, S.D.; El-Bitar, E.A.; El-Awady, M.A.; et al. (2017): "Attentiondeficit/hyperactivity disorder: Prevalence and risk factors in Egyptian primary school children". J. Community Med., 35(1): 1-16.

El-Kowrany, S. I.; El- Zamarany, E. A.; ElNouby, K.A.; et al. (2016): "Water pollution in the Middle Nile Delta, Egypt: An environmental study". J. Adv. Res., 7(5): 781-794.

El-Morsi, D.A.; El-Bakary, A.A.; Hasaneen, B.M.M.; et al. (2019): "Lead and cadmium hair levels in a sample of Egyptian children with attention deficit hyperactivity disorder". J. Clin. Toxicol., 9(1): 1-8.

El-Nemr, F.M.; Badr, H.S. and Salem, M.S. (2015): "Prevalence of attention deficit hyperactivity disorder in children". Sci. J. Public Health, 3(2): 274-280.

Farahat, T.; Alkot, M.; Rajab, A.; et al. (2014): "Attention-deficit hyperactive disorder among primary school children in Menoufia Governorate, Egypt". Int. J. Family Med., 2014: 257369.
Gomez, R.; Vance, A., and Gomez, R.M. (2016): "Maternal ratings of the ADHD Symptoms: Subtypes versus severity in clinic-referred children and adolescents". J. Attention Disord., 20(5):414-423.

Iqbal, G.; Zada, W.; Mannan, A.; et al. (2018):"Elevated heavy metals levels in cognitively impaired patients from Pakistan". Environ. Toxicol. Pharmacol., 60:100-109.

Iyare, P.U. (2019): "The effects of manganese exposure from drinking water on schoolage children: A systematic review". Neurotoxicology, 73:1-7.

Jursa, T.; Stein, C.R. and Smith, D.R. (2018): "Determinants of hair manganese, lead, cadmium and arsenic levels in environmentally exposed children". Toxics, 6(2):19-34.

Kern, J.K.; Geier, D.A.; Sykes, L.K.; et al. (2015): "Are ASD and ADHD a continuum? Comparison of pathophysiological similarities between the Disorders". J. Attention Disord., 19(9): 805-827.

Lee, M.J.; Chou, M.C.; Chou, W.J.; et al. (2018):"Heavy metals' effect on susceptibility to attention-deficit/ hyperactivity disorder: Implication of lead, cadmium, and antimony". Int. J. Environ. Res. Public Health, 15(6): 12211233.

Menezes-Filho, J.A.; Bouchard, M.; Sarcinelli, P.N., et al. (2009): "Manganese exposure and the neuropsychological effect on children and adolescents: a review". Rev. Panam. Salud. Publica, 26(6): 541-548.

Michalak, I.; Chojnacka, K. and Saeid, A. (2012): "Relation between mineral composition of human hair and common illnesses". Chin. Sci. Bull., 57:3460e3465. 
Mikulewicz, M.; Chojnacka, K. and Gedrange, T. (2013): " Reference values of elements in human hair: A systematic review". Environ. Toxicol. Pharmacol., 36: 1077-1086.

Mohamed, F.E.B.; Zaky, E.A.; El-Sayed, A.B.; et al. (2015): "Assessment of hair aluminum, lead, and mercury in a sample of autistic Egyptian children: Environmental risk factors of heavy metals in Autism". Behav. Neurol., 2015: 1-9, Article ID 545674.

Morris, G.; Puri, B.K. and Frye, R.E. (2017):"The putative role of environmental aluminum in the development of chronic neuropathology in adults and children. How strong is the evidence and what could be the mechanisms involved"? Metab. Brain Dis., 32(5): 1335-1355.

Mowlem, F.; Agnew-Blais, J.; Taylor, E.; et al. (2019):"Do different factors influence whether girls versus boys meet ADHD diagnostic criteria? Sex differences among children with high ADHD symptoms". Psychiatry Res., 272: 765773.

Ntihabose, R.; Surette, C.; Foucher, D.; et al. (2018): "Assessment of saliva, hair and toenails as biomarkers of low level exposure to manganese from drinking water in children". Neurotoxicology, 64:126-133.

O'Neal, S.L. and Zheng, W. (2015): "Manganese toxicity upon overexposure: A decade in review". Curr. Environ. Health Rep., 2(3):315-328.

Osman, N.; Zaki, A.; Agamy, N.; et al. (2017):"Aluminum in food: Dietary exposure among adolescent residents in the food catering establishments in Alexandria, Egypt". Glob. J. Pharm. Educ. Res., 6(1-2): 1-6, ISSN 2278-0580.
Oulhote, Y.; Mergler, D.; Barbeau, B. ; et al. (2014): "Neurobehavioral functionin school-age children exposed to manganese in drinking water". Environ. Health Perspect., 122(12):1343-1350.

Ptacek, R.; Kuzelova, H.; Papezova, H.; et al. (2010): "Attention deficit hyperactivity disorder and eating disorders". Prague Med. Rep., 111(3): 175-181.

Poujois, A.; Devedjian, J.C.; Moreau, C.; et al. (2016): "Bioavailable Trace Metals in Neurological Diseases". Curr. Treat. Option Neurol., 18(10):46-65.

Rodrigues, J.L.G.; Araujo, C.F.S.; Dos Santos, N.R.; et al. (2018):"Airborne manganese exposure and neurobehavior in school-aged children living near a ferro-manganese alloy plant". Environ. Res., 167: 66-77.

Sato, K.; Suzuki, I.; Kubota, H.; et al. (2014): "Estimation of daily aluminum intake in Japan based on food consumption inspection results: impact of food additives". Food Sci. Nutr., 2(4): 389-397.

Serdar, M.A.; Akin, B.S.; Razi, C.; et al. (2012):"The correlation between smoking status of family members and concentrations of toxic trace elements in the hair of children". Biol. Trace Elem. Res., 148(1):11-17.

Shaw, C.A. and Tomljenovic, L. (2013): "Aluminum in the central nervous system (CNS): toxicity in humans and animals, vaccine adjuvants, and autoimmunity". Immunol. Res., 56(2-3):304-316.

Shin, D.W.; Kim, E.J.; Lim, S.W.; et al. (2015): "Association of hair manganese level with symptoms in attentiondeficit/hyperactivity disorder". Psychiatry Investig., 12(1): 66-72.

Tippairote, T.; Temviriyanukul, P.; Benjapong, W.; et al. (2019): 
"Prevalence and factors associated with high levels of aluminum, arsenic, cadmium, lead, and mercury in hair samples of well-nourished Thai children in Bangkok and perimeters". Biol. Trace Elem. Res., 188(2): 334-343.

Tippairote, T.; Temviriyanukul, P.; Benjapong, W.; et al. (2017):"Hair zinc and severity of symptoms are increased in children with attention deficit and hyperactivity disorder: A hair multielement profile study". Biol. Trace Elem. Res., 179(2): 185-194.
Underwood, E.J. (1971): Trace Elements in Human and Animal Nutrition, $3^{\text {rd }}$ Edition, Academic Press, Inc., New York, USA.

Weidenhamer, J.D.; Fitzpatrick, M.P.; Biro, A.M.; et al. (2017):"Metal exposures from aluminum cookware: An unrecognized public health risk in developing countries". Sci. Total Environ., 579: 805-813.

Xu, Y.; Chen, X.T.; Luo, M.; et al. (2015):"Multiple epigenetic factors predict the attention deficit/hyperactivity disorder among the Chinese Han children". J. Psychiatry Res., 64: 40-50. 


\section{مستويات الألومنيوم والمنجنيز فى الشعر فى عينه من الأطفال الأصابين باضطراب نقص الانتباه و فرط الحركة فينه من الأني}

\section{رحساب محمود محملد مهنـا' - سـميرة شعبــــان حسـامد' - سلوى محمد صالاح طوبـار

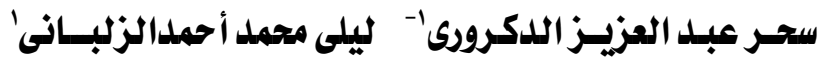

من أقسام الطب الثرعي والسموم الإكلينيكية' وقسم الطب النفسى وعلاج الإدمان ' ـ كلية الطب - جامعة المنصورة يعد اضطر اب فرط الحركة ونقص الانتباه من الاضطر ابات العصبية السلوكية الشائعة بين الأطفال.

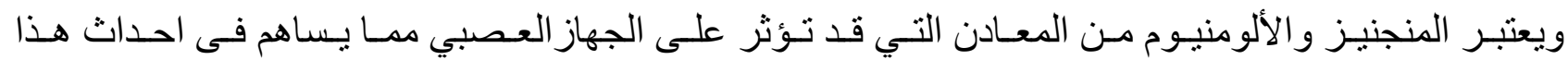
الاضطر اب. لذلك هدفت هذه الدر اسـة إلى تقييم مستوى المنجنيز و الألومنيوم في الشعر فئى عينـة مـن الأطفال

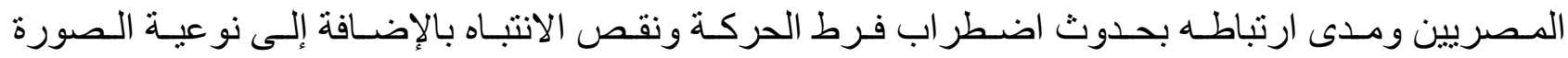

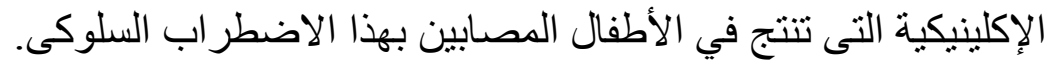

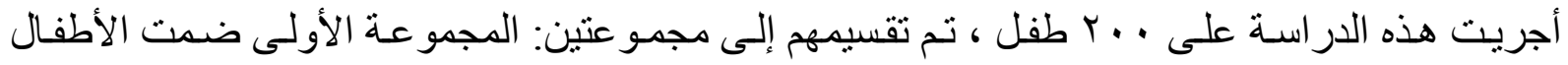

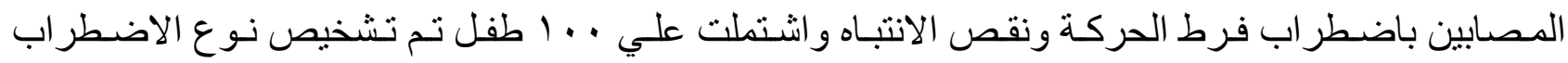

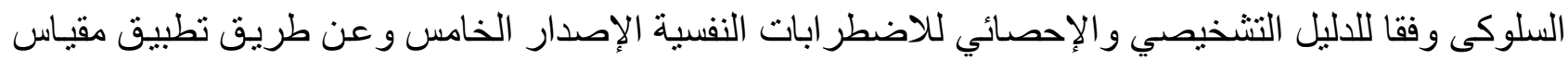

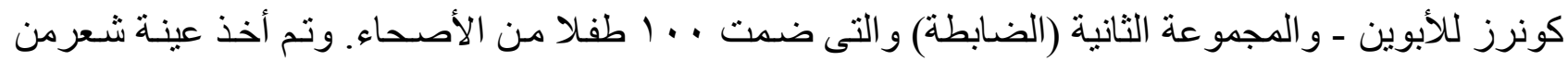

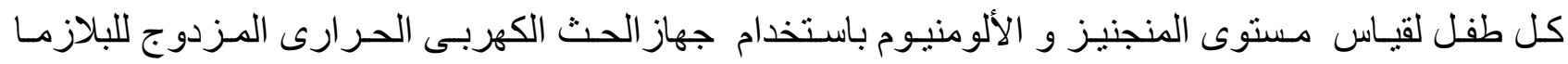
بإستخدام الإنبعاث الطيفى. وقد أظهرت هذه الدراسـة وجود فـارق ذو دلالـة إحصائية في مستوى المنجنيز في الشعر بين مجموعة

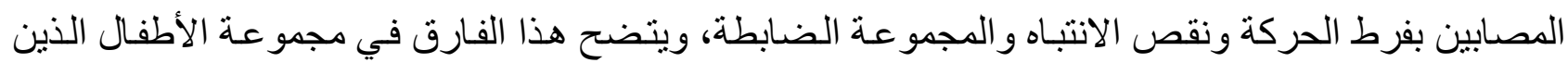
يغلب عليهم فرط الحركة.ولم يتبين وجود فارق ذو دلالة إحصائية بين المجمو عتين بالنسبة لمستوى الألومنيوم

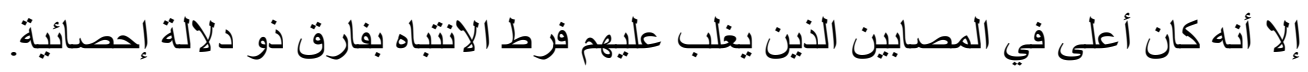

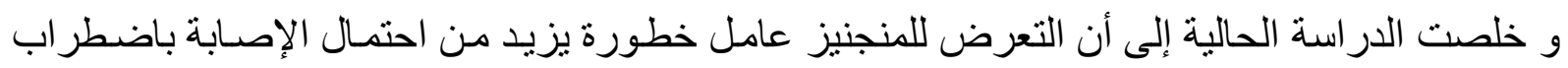
نقص الانتباه وفرط الحركة خاصـة الصورة الإكلينيكية التى يغلب فيها الاندفاعيـة وفرط الحركة على الطفل المصاب. 